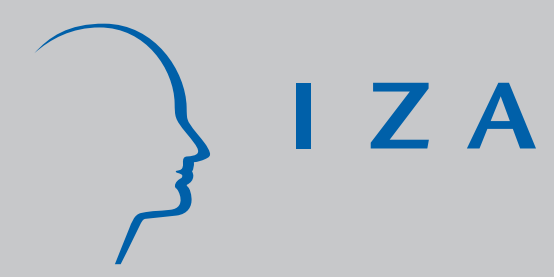

IZA DP No. 966

Optimal Taxation with Capital Accumulation and Wage Bargaining

Tapio Palokangas

December 2003 


\title{
Optimal Taxation with Capital Accumulation and Wage Bargaining
}

\author{
Tapio Palokangas \\ University of Helsinki and IZA Bonn
}

Discussion Paper No. 966

December 2003

\author{
IZA \\ P.O. Box 7240 \\ D-53072 Bonn \\ Germany \\ Tel.: +49-228-3894-0 \\ Fax: +49-228-3894-210 \\ Email: iza@iza.org
}

This Discussion Paper is issued within the framework of IZA's research area Welfare State and Labor Market. Any opinions expressed here are those of the author(s) and not those of the institute. Research disseminated by IZA may include views on policy, but the institute itself takes no institutional policy positions.

The Institute for the Study of Labor (IZA) in Bonn is a local and virtual international research center and a place of communication between science, politics and business. IZA is an independent, nonprofit limited liability company (Gesellschaft mit beschränkter Haftung) supported by Deutsche Post World Net. The center is associated with the University of Bonn and offers a stimulating research environment through its research networks, research support, and visitors and doctoral programs. IZA engages in (i) original and internationally competitive research in all fields of labor economics, (ii) development of policy concepts, and (iii) dissemination of research results and concepts to the interested public. The current research program deals with (1) mobility and flexibility of labor, (2) internationalization of labor markets, (3) welfare state and labor market, (4) labor markets in transition countries, (5) the future of labor, (6) evaluation of labor market policies and projects and (7) general labor economics.

IZA Discussion Papers often represent preliminary work and are circulated to encourage discussion. Citation of such a paper should account for its provisional character. A revised version may be available on the IZA website (www.iza.org) or directly from the author. 
IZA Discussion Paper No. 966

December 2003

\section{ABSTRACT}

\section{Optimal Taxation with Capital Accumulation and Wage Bargaining}

This study examines optimal taxation in a unionized economy in which households save capital. The main findings are as follows. Judd's (1985) and Chamley's (1986) classical results of zero taxation on capital income holds. This is true independently of workers' savings behaviour or the capitalists' weight in the social welfare function. The steady-state optimal tax rates on wages and employment are specified. The consumption tax is needed for revenue raising purposes.

JEL Classification: J51, H21

Keywords: wage settlement, optimal taxation, capital accumulation

Tapio Palokangas

Department of Economics

P.O. Box 17 (Arkadiankatu 7)

FIN-00014 University of Helsinki

Finland

Email: Tapio.Palokangas@helsinki.fi

Tel.: +358919128735

Fax: +358919128736 


\section{Introduction}

This paper examines the problem of how taxes should be determined in a unionized economy with capital accumulation. Palokangas (1987 and 2000, Ch. 4) show that in a static general equilibrium framework, aggregate production efficiency can be maintained even with labour unions as long as the government can set both a wage tax and a specific employment tax. In this study, we examine whether this result also holds true in a dynamic general equilibrium framework, in which private agents save capital and there is a strategic interdependence between investors and labour unions.

In a dynamic model with investment, aggregate production efficiency takes lines up with the Judd-Chamley assertion: capital income should be taxed at a non-zero rate. ${ }^{1}$ Because capital functions as an intermediate good, appearing only in the production but not in the utility function, it should not be taxed, if there are enough instruments to separate consumption and production decisions. Chamley (2001) shows that this assertion critically depends on the existence of a perfect bond market, in which private agents take the interest rate as given, households save in bonds, and firms can finance any amount of investment by issuing bonds. We assume here that households own firms directly. According to Palokangas (2003), zero taxation on capital income subsequently holds if the labour markets are competitive. This study extends the same result to include the case of union wage settlement.

Koskela and von Thadden (2002) show that capital income should be taxed at a non-zero rate in a unionized economy, but they assume that a labour union takes capital stock as given. It is, however, inconsistent to assume that the union takes the employment effects of its wage policy into account, but simultaneously ignores the effects through investment. In this study, we assume that the union takes the employer's investment behaviour as a constraint and show that the Judd-Chamley result still holds.

\footnotetext{
${ }^{1}$ Judd (1985), Chamley (1986) and Correia (1996).
} 
In this study, we assume that the government is the Stackelberg leader and the private agents take the government's policy instruments as given. Benhabib and Rustichini (1997), Xie (1997) and Lansing (1999) raise the question of whether public policy is consistent in such a case. Palokangas (2003) considers this issue and shows that there is indeed a reputational equilibrium with consistency. We lean on this result and assume consistency.

The remainder of this paper is organized as follows. Section 2 introduces the structure of the economy. Section 3 presents the degree of centralization and the two strategic cases of leadership. Section 4 considers investment and wage settlement, while Section 5 analyses public policy.

\section{Households, firms and the government}

There is one good which is chosen as the numeraire, and two sectors: the formal sector, which produces the good from capital and labour; and the informal sector, which cannot be taxed and which produces the good from labour only with constant returns to scale. The workers in the formal sector can form a union and raise their wage $w$ above that found in the informal sector. This two-sector framework is the simplest way to introduce union wages and distorting labour taxation into the model.

There are two groups of households. The capitalists save and earn profits and a fixed proportion $\alpha$ of the total wages $W$. The non-capitalists earn the rest $(1-\alpha)$ of total wages and consume all of their income. In this study, we use parameter $\alpha$ as a measure of income distribution. The model is an extension of two special cases. For $\alpha=0$, we obtain Judd's (1985) case in which the capitalists earn only profits and do not work, while the workers earn only wages and do not save. For $\alpha=1$, we obtain Chamley's (1986) model of a representative agent who saves and earns both wages and profits.

The whole population has the same constant rate of time preference, 
$\rho>0$. The capitalist's and non-capitalist's instantaneous utilities are

$$
U(C) \doteq \frac{C^{1-\sigma}-1}{1-\sigma}, \quad \sigma>0, \quad \sigma \neq 1, \quad V((1-\alpha) W), \quad V^{\prime}>0, \quad V^{\prime \prime}<0,
$$

where $C$ is the capitalist's consumption, $(1-\alpha) W$ the non-capitalist's income, which is wholly consumed, and constant $1 / \sigma$ the intertemporal elasticity of substitution for the capitalist. The capitalist's and the non-capitalist's utilities from a flow of consumption starting at time zero are given by

$$
\int_{0}^{\infty} U(C) e^{-\rho t} d t, \quad \int_{0}^{\infty} V((1-\alpha) W) e^{-\rho t} d t
$$

where $t$ is time. The social welfare function is a weighted average of the utilities of the two non-capitalists and capitalists:

$$
\int_{0}^{\infty}[V((1-\alpha) W)+\vartheta U(C)] e^{-\rho t} d t
$$

where constant $\vartheta>0$ is the social weight of the capitalist.

The capitalist saves only capital. In the formal sector, output is produced from capital $K$ and labour $L$ through the differentiable function

$$
Y=F(K, L), \quad F_{K}>0, F_{L}>0, F_{L L}<0, \quad F_{K K}<0, \quad F_{K L}>0,
$$

where subscripts $K$ and $L$ denote partial derivatives with respect to $K$ and $L$. Informal sector output $N$ depends on formal sector employment $L$ as:

$$
N(L), \quad N^{\prime}<0, \quad N^{\prime \prime}<0 .
$$

Hence, more and more labour must be transferred from the formal into the informal sector to produce one more unit in the latter.

At each moment of time, the government finances fixed expenditure $E$ by

$$
E=\tau_{C} C+\tau_{K} \Pi+\tau_{W} w L+\tau_{L} L
$$

where $\tau_{C}>-1, \tau_{W}>-1, \tau_{K} \leq 1$ and $\tau_{L}$ are taxes on the capitalist's consumption $C$, wages in the formal sector, $w L$, (gross) capital income $\Pi$, 
and employment in the formal sector, $L$, respectively. ${ }^{2}$ We assume a fixed upper limit $v \in[0, \infty)$ for the capital subsidy $-\tau_{K}$, so that ${ }^{3}$

$$
-v \leq \tau_{K} \leq 1
$$

Firms in the formal sector decide on their labour input $L$, taking the wage $w$ and capital $K$ as given. Noting (4), we obtain their profit as $\Pi \doteq$ $F(K, L)-v L-\mu K$, where $F(K, L)$ is output, $v \doteq\left(1+\tau_{W}\right) w+\tau_{L}$ unit labour cost and the constant $\mu \in(0,1)$ is the rate of capital depreciation. Through the maximization of profit $\Pi$, we obtain

$$
\begin{aligned}
& \Pi(K, v) \doteq \max _{L}[F(K, L)-v L-\mu K], \quad \Pi_{K} \doteq \partial \Pi / \partial K=F_{K}-\mu, \\
& \Pi_{v} \doteq \partial \Pi / \partial v=-L, \quad v=F_{L}(K, L), \quad w=\left[F_{L}(K, L)-\tau_{L}\right] /\left(1+\tau_{W}\right), \\
& \Pi_{K K} \equiv 0 \Leftrightarrow \Pi(K, v)=\max _{\ell}[F(1, \ell)-v \ell-\mu] K=\Pi_{K} K .
\end{aligned}
$$

\section{$3 \quad$ Labour unions and capitalists}

All private agents take the taxes as given. We assume that capitalists own only a small proportion of the firm in which they work, so that when deciding on saving, they take their entire labour income $\bar{W}$ as fixed. Given this, we can aggregate the firms together with their owners as the representative capitalist, who chooses investment and faces a wage-setting union.

The union observes that the capitalist's labour income is determined by

$$
\bar{W} \doteq \alpha[\beta W+(1-\beta) \widetilde{W}]
$$

where $\alpha$ is the capitalist's proportion of total wages, $W$ wages from the firms controlled by the union, $\widetilde{W}$ wages received from the other firms in the

\footnotetext{
${ }^{2}$ Because the non-capitalists do not save, but both labour income and capital income are taxed, it is all the same whether we tax total consumption $(1-\alpha) W+C$ or just the capitalist's consumption $C$. The cases $\tau_{C}=-1$ or $\tau_{W}=-1$ are not feasible, because the effective prices for consumption or labour cannot be zero for a capitalist.

${ }^{3}$ Otherwise, the subsidy $-\tau_{K}$ would get an infinite value in the government's optimal program in Section 3.
} 
economy, and the constant $\beta \in[0,1]$ is the proportion of firms controlled by the union. The union internalizes $W$, but takes $\widetilde{W}$ as given. Parameter $\beta$ can be used as a measure of the degree of centralization in wage settlement. If wage settlement is decentralized, the representative union controls a very small proportion of the firms, and we can approximate $\beta=0$. If this is centralized, the union controls all firms and consequently $\beta=1$.

Labour income $W$ is equal to income from the informal sector, $N$, plus wages in the formal sector, $w L$. Noting (4) and (8), this yields the function

$$
\begin{aligned}
& W\left(L, K, \tau_{W}, \tau_{L}\right) \doteq N(L)+w L=N(L)+\left[F_{L}(K, L)-\tau_{L}\right] L /\left(1+\tau_{W}\right), \\
& W_{L} \doteq \frac{\partial W}{\partial L}=N^{\prime}+\frac{F_{L L} L+F_{L}-\tau_{L}}{1+\tau_{W}}, \quad W_{K} \doteq \frac{\partial W}{\partial K}=\frac{F_{K L} L}{1+\tau_{W}} .
\end{aligned}
$$

The union maximizes the value of the flow of labour income, discounted by the households' rate of time preference, $\rho$, as:

$$
\int_{0}^{\infty} W\left(L, K, \tau_{W}, \tau_{L}\right) e^{-\rho t} d t
$$

The capitalist's budget constraint is given by

$$
\dot{K} \doteq d K / d t=\bar{W}+\left(1-\tau_{K}\right) \Pi(K, w)-\left(1+\tau_{C}\right) C,
$$

where $\dot{K}$ is capital accumulation. In the whole economy, capital accumulation is equal to production in the informal and formal sectors, $N(L)+F(K, L)$, minus the capitalist's consumption expenditure $\left(1+\tau_{C}\right) C$, the non-capitalist's consumption $(1-\alpha) W$, government expenditure $E$ and depreciation $\mu K$ :

$$
\dot{K}=N(L)+F(K, L)-C-(1-\alpha) W-E-\mu K .
$$

When (13) holds, the goods market is in equilibrium. Then, by Walras' law, the government budget is balanced and (6) holds as well.

\section{Investment and wage settlement}

The capitalist as the follower maximizes her utility (2) by her consumption $C$ subject to capital accumulation (12) and the functions (10), taking unit 
labour cost $v$ and her labour income $\bar{W}$ as given. Given (1) and (8), we obtain the Hamiltonian of this maximization as

$$
H^{C F}=U(C)+\theta\left[\bar{W}+\left(1-\tau_{K}\right) \Pi(K, v)-\left(1+\tau_{C}\right) C\right]
$$

where the co-state variable $\theta$ evolves according to

$$
\dot{\theta}=\rho \theta-\partial H^{C F} / \partial K=\left[\rho-\left(1-\tau_{K}\right) \Pi_{K}(K, v)\right] \theta, \quad \lim _{t \rightarrow \infty} \theta K e^{-\rho t}=0 .
$$

The first-order condition for the capitalist's maximization is given by

$$
C^{-\sigma}=U^{\prime}(C)=\left(1+\tau_{C}\right) \theta
$$

From (8), (14) and (15) it follows that

$$
\dot{C} / C=-(1 / \sigma) \dot{\theta} / \theta=\left[\left(1-\tau_{K}\right) \Pi_{K}(K, v)-\rho\right] / \sigma .
$$

Variables $K$ and $C$ are governed by (12) and (16). With decreasing returns to scale in the formal sector, $\Pi_{K K}<0$, the dynamics is as follows. Because $\frac{\partial \dot{K}}{\partial K}=\left(1-\tau_{K}\right) \Pi_{K}>0, \quad \frac{\partial \dot{K}}{\partial C}<0, \quad \frac{\partial \dot{C}}{\partial K}=\left(1-\tau_{K}\right) \Pi_{K K} \frac{C}{\sigma}<0,\left.\quad \frac{\partial \dot{C}}{\partial C}\right|_{\dot{C}=0}=0$, we obtain

$$
\frac{\partial \dot{K}}{\partial K}+\left.\frac{\partial \dot{C}}{\partial C}\right|_{\dot{C}=0}>0,\left.\quad \frac{\partial \dot{K}}{\partial K} \frac{\partial \dot{C}}{\partial C}\right|_{\dot{C}=0}<\frac{\partial \dot{K}}{\partial C} \frac{\partial \dot{C}}{\partial K}
$$

and there is a saddle-point solution. Hence, the co-state variable $C$ (which represents $\theta$ ) jumps onto the saddle path which leads to the steady state in which $K, C$ and $\lambda$ are constants, and $\lim _{t \rightarrow \infty} \theta K e^{-\rho t}=0$ holds.

With constant returns to scale in the formal sector, $\Pi_{K K} \equiv 0$, given (8), (12) and (14), we obtain

$$
\left[\frac{\dot{K}}{K}+\frac{\dot{\theta}}{\theta}-\rho\right]_{\dot{K}=0}=\left[\frac{\bar{W}}{K}-\left(1+\tau_{C}\right) \frac{C}{K}\right]_{\dot{K}=0}=\left(\tau_{K}-1\right) \Pi_{K}<0 .
$$

This implies the transversality condition $\lim _{t \rightarrow \infty} K \theta e^{-\rho t} d t=0$. 
The union as the leader sets its wage $w$ to maximize its welfare (11), given the Euler equation (16), capital accumulation (12) and the capitalist's labour income (9), where it internalizes its members' labour income $W$ by (10). Because there is a one-to-one correspondence from $w$ to $L$ through (8), the wage $w$ can be replaced by formal-sector employment $L$ as the union's policy instrument. This maximization leads to the Hamiltonian

$$
\begin{aligned}
H= & W\left(L, K, \tau_{W}, \tau_{L}\right)+\xi\left\{\left(1-\tau_{K}\right)\left[F_{K}(K, L)-\mu\right]-\rho\right\} C / \sigma+\phi\{(1-\beta) \alpha \widetilde{W} \\
& \left.+\alpha \beta W\left(L, K, \tau_{W}, \tau_{L}\right)+\left(1-\tau_{K}\right) \Pi\left(K, F_{L}(K, L)\right)-\left(1+\tau_{C}\right) C\right\}
\end{aligned}
$$

where the co-state variables $\xi$ and $\phi$ evolve according to

$$
\begin{aligned}
& \dot{\xi}=\rho \xi-\partial H / \partial C=\left\{\rho+\rho / \sigma-\left(1-\tau_{K}\right)\left[F_{K}(K, L)-\mu\right] / \sigma\right\} \xi+\left(1+\tau_{C}\right) \phi \\
& \lim _{t \rightarrow \infty} \xi C e^{-\rho t}=0 \\
& \dot{\phi}=\rho \phi-\partial H / \partial K=\left[\rho-\left(1-\tau_{K}\right)\left(\Pi_{K}+\Pi_{v} F_{K L}\right)\right] \phi-(\alpha \beta \phi+1) W_{K} \\
& \lim _{t \rightarrow \infty} \phi K e^{-\rho t}=0 .
\end{aligned}
$$

The first-order condition for $L$ is given by

$$
\partial H / \partial L=(1+\alpha \beta \phi) W_{L}+\left(1-\tau_{K}\right)\left[F_{K L} \xi C / \sigma+\Pi_{v} F_{L L} \phi\right]=0
$$

which is equivalent to $1+\alpha \beta \phi=\left(\tau_{K}-1\right)\left[F_{K L} \xi C / \sigma+\Pi_{v} F_{L L} \phi\right] / W_{L}$. Inserting this into (19) yields

$$
\begin{gathered}
\dot{\phi}=\left[\rho-\left(1-\tau_{K}\right)\left(\Pi_{K}+\Pi_{v} F_{K L}\right)\right] \phi+\left(1-\tau_{K}\right)\left[F_{K L} \xi C / \sigma+\Pi_{v} F_{L L} \phi\right] W_{K} / W_{L} \\
\lim _{t \rightarrow \infty} \phi K e^{-\rho t}=0 .
\end{gathered}
$$

The initial values of the co-state variables $\xi$ and $\phi$ can be chosen freely, provided that the transversality conditions $\lim _{t \rightarrow \infty} \xi C e^{-\rho t}=0$ and $\lim _{t \rightarrow \infty} \phi K e^{-\rho t}=0$ hold. Choosing the initial values $\xi(0)=0$ and $\phi(0)=0$, we obtain from (18) and (21) that $\xi \equiv 0$ and $\phi \equiv 0$. The first-order condition (20) then takes the form $W_{L}=0$. Hence, in the steady state, the optimal 
strategy for the union is to maximize labour income $W$ by formal-sector employment $L$, given taxes $\left(\tau_{L}, \tau_{W}\right)$ and capital stock $K$. If capital stock is at the optimal level from the union's viewpoint, it is enough for the union to balance the marginal income of a wage increase with the marginal loss of income due to lower employment. This result, (8) and (10) yields:

$$
\begin{aligned}
& L\left(K, \tau_{W}, \tau_{L}\right) \doteq \arg \max _{L} W\left(L, K, \tau_{W}, \tau_{L}\right), \quad L_{K}\left(K, \tau_{W}\right) \doteq \partial L / \partial K, \\
& \tau_{L}-\left(1+\tau_{W}\right) N^{\prime}(L)=F_{L}(K, L)+F_{L L}(K, L) L=(1-1 / \epsilon) F_{L}, \\
& v\left(K, \tau_{W}, \tau_{L}\right) \doteq F_{L}\left(K, L\left(K, \tau_{W}, \tau_{L}\right)\right), \quad v_{K}\left(K, \tau_{W}, \tau_{L}\right) \doteq \partial v / \partial K
\end{aligned}
$$

where $\epsilon \doteq-F_{L} /\left(L F_{L L}\right)>0$ is the elasticity of formal-sector employment $L$ with respect to unit labour cost $v$.

\section{$5 \quad$ Policy rules}

The government sets taxes $\left(\tau_{C}, \tau_{L}, \tau_{W}, \tau_{K}\right)$ to maximize social welfare (3) subject to capital accumulation (13), the Euler equation (16), equations (19) and constraints (7). Because there is a one-to-one correspondence from $\left(\tau_{L}, \tau_{W}\right)$ to the values of the functions $W$ and $L$ through (10) and $(20),\left(\tau_{L}, \tau_{W}\right)$ can be replaced by $(W, L)$ as control variables. Noting (1), this leads to the Hamiltonian and the Lagrangean

$$
\begin{aligned}
H^{G}= & \left.V((1-\alpha) W)+\vartheta U(C)+\gamma\left\{\left(1-\tau_{K}\right)\left[F_{K}(K, L)\right)-\mu\right]-\rho\right\} C / \sigma \\
& +\chi[(\alpha-1) W+N(L)+F(K, L)-C-\mu K], \\
\mathcal{L}^{G}= & H^{G}+\nu_{1}\left[\tau_{K}+v\right]+\nu_{2}\left[1-\tau_{K}\right],
\end{aligned}
$$

where the co-state variables $\chi$ and $\gamma$ evolve according to

$$
\begin{aligned}
& \dot{\gamma}=\rho \gamma-\partial H^{G} / \partial C=\left[\rho+\rho / \sigma-\left(1-\tau_{K}\right)\left(F_{K}-\mu\right) / \sigma\right] \gamma+\chi-\vartheta C^{-\sigma}, \\
& \dot{\chi}=\rho \chi-\partial H^{G} / \partial K=\left[\rho+\mu-F_{K}(K, L)\right] \chi+\left(\tau_{K}-1\right) F_{K K} C \gamma / \sigma, \\
& \lim _{t \rightarrow \infty} \chi K e^{-\rho t}=0, \lim _{t \rightarrow \infty} \gamma C e^{-\rho t}=0,
\end{aligned}
$$


and variables $\nu_{1}$ and $\nu_{2}$ satisfy the Kuhn-Tucker conditions

$$
\nu_{1}\left[\tau_{K}+v\right]=0, \quad \nu_{1} \geq 0, \quad \nu_{2}\left[1-\tau_{K}\right]=0, \quad \nu_{2} \geq 0
$$

Noting (23), the first-order condition for $\tau_{K}$ is given by

$$
\partial H^{G} / \partial \tau_{K}=\left(\mu-F_{K}\right)(C / \sigma) \gamma+\nu_{1}-\nu_{2}=0
$$

Assume first $-v<\dot{C}<v$, so that $\nu_{1}=\nu_{2}=0$. Because $\partial^{2} H^{G} / \partial \tau_{K}^{2} \equiv 0$, we have to solve for $\tau_{K}$ through the generalized Clebsch-Legendre conditions: ${ }^{4}$

$$
\begin{aligned}
& \frac{\partial}{\partial \tau_{K}}\left(\frac{d^{p}}{d t^{p}} \frac{\partial H^{G}}{\partial \tau_{K}}\right)=0 \text { for any odd integrer } p \\
& (-1)^{q} \frac{\partial}{\partial \tau_{K}}\left(\frac{d^{2 q}}{d t^{2 q}} \frac{\partial H^{G}}{\partial \tau_{K}}\right) \geq 0 \text { for any integrer } q,
\end{aligned}
$$

where $t$ is time. Because $C>0$ and $F_{K}>\mu$, equation (26) yields $\gamma=0$. Differentiating (26) with respect to time $t$ and noting (8), (16), (24) and $\gamma=0$, we see that the Clebsch-Legendre conditions (27) hold as follows:

$$
\begin{aligned}
& \frac{d}{d t}\left(\frac{\partial H^{G}}{\partial \tau_{K}}\right)=\left.\left(\mu-F_{K}\right) \frac{C}{\sigma} \dot{\gamma}\right|_{\gamma=0}=\Pi_{K} \frac{C}{\sigma}\left[\vartheta C^{-\sigma}-\chi\right]=0, \\
& \frac{\partial}{\partial \tau_{K}} \frac{d}{d t}\left(\frac{\partial H^{G}}{\partial \tau_{K}}\right)=0, \quad \frac{d^{2}}{d t^{2}}\left(\frac{\partial H^{G}}{\partial \tau_{K}}\right)=-\Pi_{K} \frac{C}{\sigma}\left[\dot{\chi}+\sigma \vartheta C^{-\sigma-1} \dot{C}\right]=0, \\
& \frac{\partial}{\partial \tau_{K}} \frac{d^{2}}{d t^{2}}\left(\frac{\partial H^{G}}{\partial \tau_{K}}\right)=-\Pi_{K} \frac{C}{\sigma}\left[\frac{\partial \dot{\chi}}{\partial \tau_{K}}+\frac{\sigma \vartheta}{C^{\sigma+1}} \frac{\partial \dot{C}}{\partial \tau_{K}}\right]=\Pi_{K}^{2} \frac{\vartheta}{\sigma} C^{1-\sigma}>0 .
\end{aligned}
$$

Given (28), we obtain

$$
\chi=\vartheta C^{-\sigma}
$$

From $\gamma=0,(8),(16),(24),(29)$ and (31) it follows that

$$
\begin{aligned}
0 & =\dot{\chi}+\sigma \vartheta C^{-\sigma-1} \dot{C}=\left(\rho+\mu-F_{K}\right) \chi+\vartheta C^{-\sigma}\left[\left(1-\tau_{K}\right) \Pi_{K}-\rho\right] \\
& =\left(\rho-\Pi_{K}\right) \vartheta C^{-\sigma}+\vartheta C^{-\sigma}\left[\left(1-\tau_{K}\right) \Pi_{K}-\rho\right]=-\vartheta C^{-\sigma} \tau_{K} \Pi_{K}
\end{aligned}
$$

which is equivalent to $\tau_{K}=0$. This yields the following result:

\footnotetext{
${ }^{4}$ Cf. Bell and Jacobson (1975), p. 12-19.
} 
Proposition 1 The steady-state capital tax $\tau_{K}=0$ should be zero.

Noting $\gamma=0$ and (23), the first-order conditions for $W$ and $L$ are

$$
\partial H^{G} / \partial W=(1-\alpha)\left(V^{\prime}-\chi\right)=0, \partial H^{G} / \partial L=\chi\left(N^{\prime}+F_{L}\right)=0
$$

Given (22), (31) and (32), we obtain $F_{L}=-N^{\prime}, \vartheta C^{-\sigma}=\chi=V^{\prime}$ and the following results:

Proposition 2 ( $i$ ) In the steady state, labour income $W$ should be kept by the wage tax $\tau_{W}$ such that the marginal utility of income for the non-capitalist, $V^{\prime}$, is equal to that for the capitalist, $C^{-\sigma}$, times the latter's social weight $\vartheta$.

(ii) The steady-state employment subsidy $-\tau_{L}$ should be equal to $\left(1 / \epsilon+\tau_{W}\right) v$, where $\epsilon$ is the wage elasticity of formal-sector employment, $\tau_{W}$ the wage tax and $v$ unit labour cost. This equalizes the marginal product of labour in the two sectors, $F_{L}=-N^{\prime}$, in the steady state.

Result $(i)$ means that the wage tax should be used to maintain socially optimal income distribution. Result $(i i)$ can be interpreted as follows. The less elastic the formal-sector employment is with respect to the wage (i.e. the higher $1 / \epsilon)$, the higher the union's monopoly power, and the larger employment subsidy is needed to keep the wage in the formal sector equal to the marginal product of labour in the informal sector.

The system (13) and (16) produces a steady state in which capital stock $K$ and the capitalist's consumption $C$ are kept constant. Given $\dot{C}=0$, (8), (16) and proposition 1, we obtain $\rho=F_{K}(K, L)-\mu=\Pi_{K}$. From this and proposition $2(i i)$, it follows that the value $\left(K^{*}, L^{*}\right)$ for $(K, L)$ in the steady state with $\gamma=0$ is determined by two equations $F_{K}\left(K^{*}, L^{*}\right)=\rho+\mu$ and $F_{L}\left(K^{*}, L^{*}\right)=-N^{\prime}\left(L^{*}\right)$. Given (25) and (26), we obtain the following. If $\gamma>0(\gamma<0)$, then the capital subsidy (tax) should be raised to the maximum, $-\tau_{W}=v\left(\tau_{W}=1\right)$, so that the capitalist accumulates (exhausts) capital, $\dot{K}>0(\dot{K}>0)$. This result can be rephrased as: 
Proposition 3 The equilibrium values $K^{*}$ and $L^{*}$ for capital $K$ and formalsector employment $L$ are given by $F_{K}\left(K^{*}, L^{*}\right)=\rho+\mu$ and $F_{L}\left(K^{*}, L^{*}\right)=$ $-N^{\prime}\left(L^{*}\right)$. The government should encourage (discourage) investment as long as capital $K$ is above (below) its equilibrium level $K^{*}, \dot{K}>0(\dot{K}<0)$.

Because the system ends up with a steady state in which $K, C, \chi$ and $\gamma$ are constants, conditions $\lim _{t \rightarrow \infty} K \chi e^{-\rho t}=0$ and $\lim _{t \rightarrow \infty} C \gamma e^{-\rho t}=0$ hold.

\section{Conclusions}

This paper examines optimal taxation in an economy with two sectors: a formal sector which can be taxed, and an informal sector which cannot. Workers in the formal sector form a union, which raises their wage above the wage found in the informal sector. Some (or all) households specified as capitalists save and earn a fixed proportion of all wages, while the others specified as non-capitalists spend all of their income. A labour union takes the firms' and capitalists' employment and investment behaviour as constraints in wage settlement. Wages are determined at the level of a single firm, at the level of the whole economy, or at some intermediate level. The government can tax consumption, employment, wages and capital income. The main findings of this paper are the following.

Zero taxation of capital income applies to unionized economies. Aggregate production efficiency can be maintained by the taxes on consumption, wages and formal-sector employment. The wage tax should be set so as to keep the marginal utility of a non-capitalist equal to the marginal utility of a capitalist times the capitalists' weight in the social welfare function. The employment subsidy is needed to change the slope of the labour demand curve, so that the union sets its wage equal to the marginal product of labour in the informal sector. Consumption should be taxed for revenue-raising purposes. These tax rules hold for any degree of centralization in wage settlement and for any proportion of wages earned by the capitalists. 


\section{References:}

Basar, T. and Olsder G.J. (1989). Dynamic Cooperative Game Theory. London: Academic Press.

Bell, D.J. and Jacobson D.H. (1975). Singular Optimal Control Problems. New York: Academic Press.

Benhabib, J. and Rustichini, A. (1997). Optimal Taxes without Commitment. Journal of Economic Theory 77: 231-59.

Chamley, C. (1986). Optimal Taxation of Capital Income in General Equilibrium with Infinite Lives. Econometrica 54: 607-22.

Chamley, C. (2001). Capital Income Taxation, Wealth Distribution and Borrowing Constraints. Journal of Public Economics 79: 55-69.

Correia, I.H. (1996). Should Capital Income be Taxed in the Steady State? Journal of Public Economics 60: 147-51.

Judd, K.L. (1985). Redistributive Taxation in a Simple Perfect Foresight Model. Journal of Public Economics 28: 59-83.

Koskela, E. and von Thadden, L. (2002). Optimal Factor Taxation under Wage Bargaining - a Dynamic Perspective. A paper presented in the EALE 2003 conference, Seville, Spain.

Lansing, K.J. (1999). Optimal Redistributive Capital Taxation in a Neoclassical Growth Model. Journal of Public Economics 73: 423-453.

Palokangas, T. (1987). Optimal Taxation and Employment Policy with a Centralized Wage Setting. Oxford Economic Papers 39: 799-812.

Palokangas, T. (2000). Labour Unions, Public Policy and Economic Growth. Cambridge (U.K.): Cambridge University Press.

Palokangas, T. (2003). Credibility in Optimal Factor Taxation. Department of Economics, University of Helsinki, Discussion Paper No. 583:2003. Downloadable at: http://ethesis.helsinki.fi/valkandis.html 


\section{IZA Discussion Papers}

\begin{tabular}{|c|c|c|c|c|}
\hline No. & Author(s) & Title & Area & Date \\
\hline 951 & $\begin{array}{l}\text { P. Garibaldi } \\
\text { E. Wasmer }\end{array}$ & $\begin{array}{l}\text { Raising Female Employment: Reflexions and } \\
\text { Policy Tools }\end{array}$ & 5 & $12 / 03$ \\
\hline 952 & $\begin{array}{l}\text { O. Raaum } \\
\text { K. G. Salvanes } \\
\text { E. Ø. Sørensen }\end{array}$ & The Neighbourhood Is Not What It Used to Be & 3 & $12 / 03$ \\
\hline 953 & $\begin{array}{l}\text { O. Raaum } \\
\text { K. G. Salvanes } \\
\text { E. Ø. Sørensen }\end{array}$ & $\begin{array}{l}\text { The Impact of a Primary School Reform on } \\
\text { Educational Stratification: A Norwegian Study of } \\
\text { Neighbour and School Mate Correlations }\end{array}$ & 5 & $12 / 03$ \\
\hline 954 & $\begin{array}{l}\text { P. Portugal } \\
\text { J. T. Addison }\end{array}$ & Six Ways to Leave Unemployment & 6 & $12 / 03$ \\
\hline 955 & V. Grossmann & $\begin{array}{l}\text { Risky Human Capital Investment, Income } \\
\text { Distribution, and Macroeconomic Dynamics }\end{array}$ & 5 & $12 / 03$ \\
\hline 956 & $\begin{array}{l}\text { M. Fertig } \\
\text { C. M. Schmidt }\end{array}$ & $\begin{array}{l}\text { Gerontocracy in Motion? European Cross- } \\
\text { Country Evidence on the Labor Market } \\
\text { Consequences of Population Ageing }\end{array}$ & 5 & $12 / 03$ \\
\hline 957 & $\begin{array}{l}\text { M. Ebell } \\
\text { C. Haefke }\end{array}$ & $\begin{array}{l}\text { Product Market Deregulation and Labor Market } \\
\text { Outcomes }\end{array}$ & 6 & $12 / 03$ \\
\hline 958 & $\begin{array}{l}\text { T. Brück } \\
\text { J. P. Haisken-DeNew } \\
\text { K. F. Zimmermann }\end{array}$ & $\begin{array}{l}\text { Creating Low Skilled Jobs by Subsidizing } \\
\text { Market-Contracted Household Work }\end{array}$ & 5 & $12 / 03$ \\
\hline 959 & $\begin{array}{l}\text { T. Bauer } \\
\text { H. Bonin } \\
\text { U. Sunde }\end{array}$ & $\begin{array}{l}\text { Real and Nominal Wage Rigidities and the Rate } \\
\text { of Inflation: Evidence from West German Micro } \\
\text { Data }\end{array}$ & 1 & $12 / 03$ \\
\hline 960 & $\begin{array}{l}\text { A. Constant } \\
\text { K. F. Zimmermann }\end{array}$ & $\begin{array}{l}\text { Circular Movements and Time Away from the } \\
\text { Host Country }\end{array}$ & 1 & $12 / 03$ \\
\hline 961 & $\begin{array}{l}\text { C. N. Teulings } \\
\text { C. G. de Vries }\end{array}$ & $\begin{array}{l}\text { Generational Accounting, Solidarity and Pension } \\
\text { Losses }\end{array}$ & 3 & $12 / 03$ \\
\hline 962 & $\begin{array}{l}\text { L. Goerke } \\
\text { M. Pannenberg }\end{array}$ & $\begin{array}{l}\text { Norm-Based Trade Union Membership: } \\
\text { Evidence for Germany }\end{array}$ & 3 & $12 / 03$ \\
\hline 963 & $\begin{array}{l}\text { L. Diaz-Serrano } \\
\text { J. Hartog } \\
\text { H. S. Nielsen }\end{array}$ & $\begin{array}{l}\text { Compensating Wage Differentials for } \\
\text { Schooling Risk in Denmark }\end{array}$ & 5 & $12 / 03$ \\
\hline 964 & $\begin{array}{l}\text { R. Schettkat } \\
\text { L. Yocarini }\end{array}$ & $\begin{array}{l}\text { The Shift to Services: } \\
\text { A Review of the Literature }\end{array}$ & 5 & $12 / 03$ \\
\hline 965 & $\begin{array}{l}\text { M. Merz } \\
\text { E. Yashiv }\end{array}$ & Labor and the Market Value of the Firm & 1 & $12 / 03$ \\
\hline 966 & T. Palokangas & $\begin{array}{l}\text { Optimal Taxation with Capital Accumulation } \\
\text { and Wage Bargaining }\end{array}$ & 3 & $12 / 03$ \\
\hline
\end{tabular}

An updated list of IZA Discussion Papers is available on the center's homepage www.iza.org. 